\title{
Comparative Analysis of Minimally Invasive Microductectomy Versus Major Duct Excision in the Diagnosis and Treatment of Patients with Pathological Nipple Discharge
}

\author{
Kenan Çetin, Hasan Ediz Sıkar, Metin Kement, Muhammet Fikri Kündeş, \\ Mehmet Eser, Ersin Gündoğan, Levent Kaptanoğlu, Nejdet Bildik
}

Department of General Surgery, University of Health Sciences, Kartal Dr. Lütfi Kırdar Education and Research Hospital, İstanbul, Turkey

Submitted: 25.02.2017 Accepted: 14.07.2017

Correspondence: Kenan Çetin, Yakacık Yeni Mahalle, Yürek Kayalar Sk., Aşiyan Apt., No: 30, D: 2, İstanbul, Turkey E-mail: drkenancetin@hotmail.com

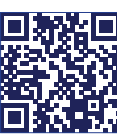

Keywords: Major duct excision; microductectomy; nipple discharge.

\begin{abstract}
Objective: The present study is a comparison of results in patients with pathological nipple discharge (PND) who underwent microductectomy and those who underwent major duct excision (MDE).

Methods: This study included patients who underwent surgery in the clinic due to PND between October 2015 and October 20II. Data were collected via retrospective chart review. The patients were divided into 2 groups according to the type of surgery (Group Micro and Group Major). The demographic characteristics of the patients, the character of the discharge, preoperative imaging findings, preoperative cytological findings, postoperative pathological findings, and follow-up results were analyzed.
\end{abstract}

Results: The records of a total of 78 patients were examined. Group Micro comprised 57 patients, and 21 were included in Group Major. The most frequently observed lesion in both groups was papillomatous lesion without atypia (Group Major: $n=8,38.1 \%$ and Group Micro: $n=26,45.6 \%$ ). Premalignant lesion was detected in 17 patients (atypical ductal hyperplasia, papillomatous lesion with atypia, ductal carcinoma in situ, intraductal papillary carcinoma). Although the number of patients with a premalignant lesion in Group Major was greater than that seen in Group Minor, the difference was not significant $(n=11,19.3 \%$ and $n=6,28.6 \%$, respectively; $\mathrm{p}=0.3$ ).

Conclusion: Conventional imaging and cytology techniques are usually insufficient in the diagnosis of PND. Therefore, surgery is frequently required in these patients. Microductectomy or MDE may be selected as the preferred surgical procedure. In this study, the results of the 2 procedures were found to be similar.

\section{INTRODUCTION}

Nipple discharge constitutes the third most common reason for presentation at a breast polyclinic, following mastalgia and palpable mass, and it accounts for approximately $5 \%$ to $7 \%$ of all visits. ${ }^{[1,2]}$ Nipple discharge is classified as non-pathological or pathological, according to the features present. Non-pathological discharge is generally bilateral, multi-ductal, nonspontaneous, and milky-green in color. ${ }^{[3]}$ This is the most common type of discharge in women of reproductive age and does not necessitate any examination or treatment. On the other hand, pathological nipple discharge (PND) is spontaneous, unilateral, mono-ductal, and may be bloody, serous or serenergic. . $^{[3,4]}$ Pre-malignant or malignant lesions constitute the source of the discharge in $5 \%$ to $28 \%$ of PND cases. ${ }^{[5,6]}$ As such, the etiology of 
PND must be researched very carefully.

Though recent developments, such as imaging methods, endoscopic instruments (ductoscopy), and examination of discharge samples at the molecular level, are important in the diagnosis and treatment of PND, ${ }^{[7,8]}$ unfortunately, none has sufficient value (sensitivity and specificity) for diagnostic purposes and invasive procedures are generally required. These procedures are also usually remedial. There are 2 techniques performed: The first and oldest method is major ductal excision (MDE), which involves the excision of all subareolar ducts of the breast with PND, while the other is the minimally invasive microductectomy, which seeks to excise only the duct with a pathological flow.

This study is a comparison of results of MDE and microductectomy procedures performed in patients diagnosed with PND.

\section{MATERIAL AND METHODS}

\section{Study design and patients}

Patients who were operated on for PND in the General Surgery Clinic of Kartal Training and Research Hospital between October $201 \mathrm{I}$ and October 2015 were included in the study. The data were collected retrospectively from patient files. Approval was granted by the ethics committee of the hospital prior to commencing the study. The patients were separated into 2 groups according to surgical procedure: the patients who underwent microductectomy were included in Group Micro, and the patients who had MDE performed were included in Group Major.

\section{Technical details of procedures}

In a microductectomy, while the patient is under general anesthesia in the supine position, discharge is provoked by massage of the breast to determine the pathological duct (Figure la). The pathological duct is then cannulated utilizing 2.0 Prolene suture (Ethicon, Inc., Somerville, NJ, USA). A blue angiocath is inserted via the suture and the channel is intubated. The pathological duct is marked with I to 2 cc of methylene blue (Figures Ib-d). Subsequently, an incision is made in the periareolar region and dissection is continued in clockwise direction until the duct stained with dye is reached and to the back of the papilla (Figure $2 a)$. The duct and related branches are excised. Subcutaneous closure of the tissue is performed to complete the procedure (Figures $2 b-d$ ). The proximal side of the duct of the pathology sample is marked with suture material to guide pathological examination (Figure 2e).

In MDE, all of the major ducts to the papilla are excised via inferior periareolar incision.
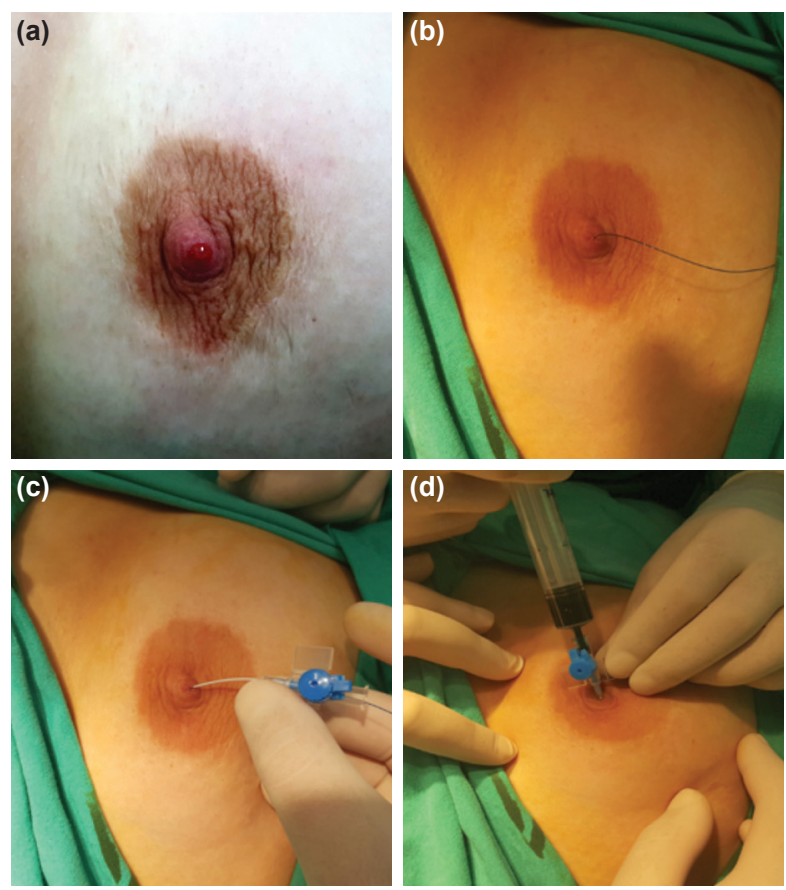

Figure 1. (a-d) Marking the pathological duct.

\section{Exclusion criteria}

Patients with palpable mass lesion diagnosed as malignant based on biopsy, patients with suspicious malignancy (Breast Imaging-Reporting and Data System 4b-c-5) according to imaging methods, and patients with previously identified breast cancer in the same breast were excluded from the study.

\section{Examined data}

The data analyzed comprise demographic features of patients (age, sex, menopausal status), character of the discharge, preoperative imaging findings, preoperative cytological findings, postoperative pathological findings, and follow-up results.

\section{Statistical analysis}

Patient data were analyzed using IBM SPSS Statistics for Windows, Version 20.0 (IBM Corp., Armonk, NY, USA). Parametric data were compared with Student's t-test, while categorical data were compared using chi-square test. The difference was deemed to be significant if the $P$ value was less than 0.05 .

\section{RESULTS}

\section{Patients}

In all, 80 patients were operated on in the clinic as a result of nipple discharge during the period of the study. Two patients were excluded according to the criteria stated, 

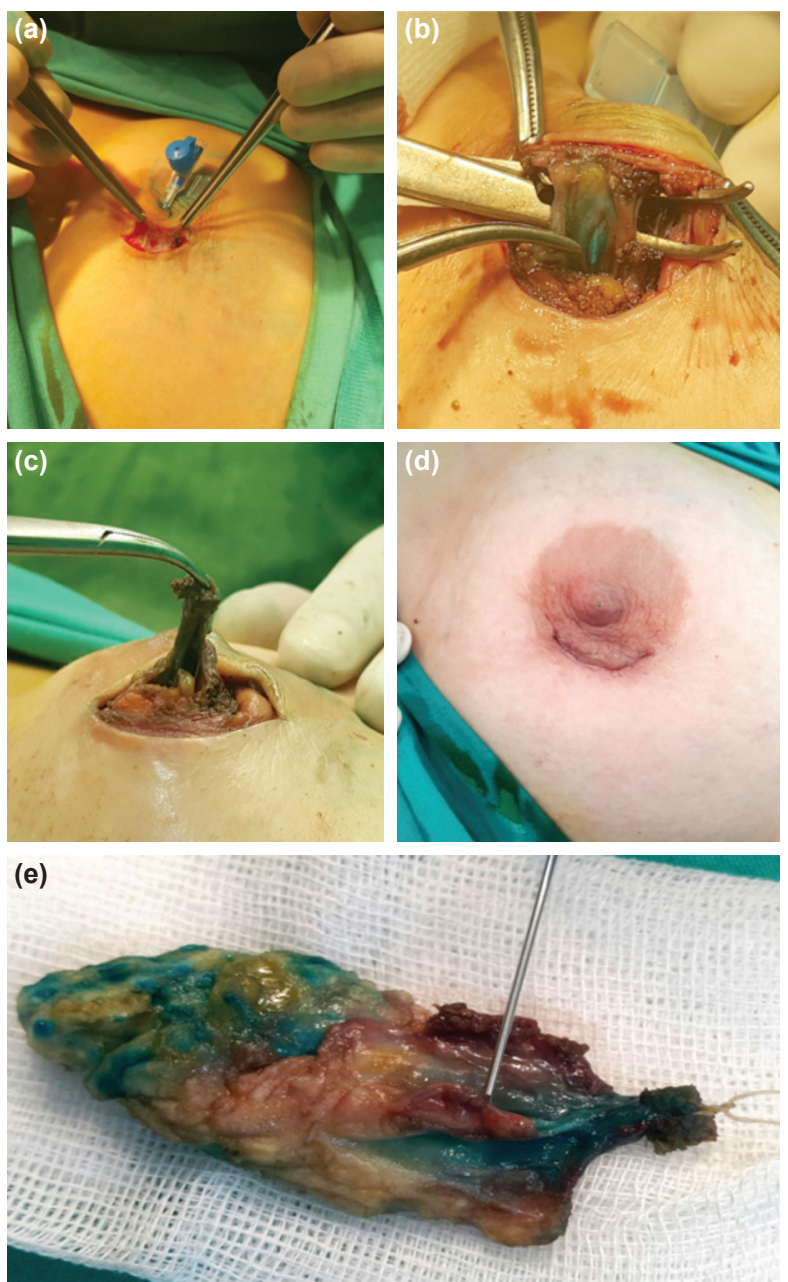

Figure 2. (a-e) Excision of the pathological duct via periareolar incision and the pathology sample.

and 78 patients were included. Microductectomy (Group Micro) was performed in 57 patients and MDE (Group Major) was performed in 21 .

\section{Demographic findings}

All of the patients in the study but I were women (98.7\%). The average age was $47.1 \pm 12.4$ years. The demographic features of the patients in both groups were found to be similar (Table I).

\section{Discharge character and preoperative examination}

The characteristics of the discharge observed, preoperative imaging, and cytological findings were similar in both groups (Table 2).

\section{Pathology findings}

Intraductal lesions of various types were found in 50 (64.1\%) of the patients. The most frequently detected lesion observed in both groups in this study was papil-
Table I. Demographic features of patients

\begin{tabular}{lccc}
\hline Parameters & $\begin{array}{c}\text { Group Micro } \\
(\mathbf{n}=57)\end{array}$ & $\begin{array}{c}\text { Group Major } \\
(\mathbf{n = 2 1 )}\end{array}$ & p \\
\hline Age \pm SD (years) & $46.3 \pm 12.4$ & $49.2 \pm 12.5$ & 0.3 \\
& $(23-74)$ & $(27-67)$ & \\
Gender (female, \%) & $57(100)$ & $20(95.2)$ & 0.1 \\
Menopausal status & $27(47)$ & $9(45)$ & 0.85 \\
(pre-menopausal, \%) & & & \\
\hline
\end{tabular}

lomatous lesion(s) without atypia (Group Major: $n=8$, $38.1 \%$, and Group Micro: n=26, 45.6\%) (Table 3). Papillomatous lesion(s) with potential malignancy was detected in $17(21.8 \%)$ patients (atypical ductal hyperplasia $[\mathrm{n}=2$, $2.6 \%$, with atypia $[n=5,6.4 \%]$, ductal carcinoma in situ [DCIS; $n=6,7.7 \%$, and intraductal papillary carcinoma $[n=4,5.1 \%])$. Although the number of patients with potentially malignant lesions was greater in Group Major than in Group Minor (28.6\% vs 19.3\%), the difference was not statistically significant $(p=0.3)$. Invasive cancer was not detected in any of the patients in this study. The pathological findings of the study patients are provided in Tables 3 and 4.

\section{Clinical outcomes}

Postoperative symptomatic relief was achieved in all patients and no postoperative complication was seen. MDE was performed in I patient (I.3\%) with intraductal papilloma because in the first month after the initial microductectomy, discharge appeared from a new duct of the same breast. The last pathology result for this patient reported it as a foreign body reaction. One patient in Group Micro whose pathology result was reported as DCIS had extensive local excision to obtain adequate surgical border.

\section{DISCUSSION}

Though most often nipple discharge is non-pathological, it can be a very worrying symptom for patients. Bloody discharge, in particular, may affect the patient psychologically. Spontaneous, unilateral, single-duct, bloody or serous discharge, in addition to pregnancy and lactation, is defined as PND. The most frequent cause of PND is a benign breast lesion, such as a solitary intraductal papilloma or papillomatosis (35\%-48\%); however, sometimes discharge can be a precursor of malignancy. ${ }^{[4]}$ For this reason, surgeons have to evaluate the patient's complaints and symptoms carefully.

The main target in the treatment of nipple discharge is to exclude an underlying malignancy, rather than removing the cause of the discharge. In most cases without a palpable mass, no lesion can be detected using imaging 
Table 2. Comparison of preoperative findings

\begin{tabular}{|c|c|c|c|}
\hline Parameters & Group Micro $(n=57)$ & Group Major $(n=2 I)$ & $\mathbf{p}$ \\
\hline Side (right, \%) & $29(5 \mathrm{I})$ & II (52) & 0.9 \\
\hline Number of pathological criteria & $40-14-3$ & $|5-5-|$ & 0.9 \\
\hline $3-2-1$ (\%) & $(70-25-5)$ & $(7 \mid-24-5)$ & \\
\hline Type of flow & $14-22-12-9$ & $5-8-5-3$ & 0.9 \\
\hline Bloody-serous-seroanginous -other (\%) & $(25-39-21-15)$ & $(24-38-24-14)$ & \\
\hline Mammographic findings & $|2-3|-7-7-0-0$ & $6-7-5-2-0-1$ & 0.4 \\
\hline None-BIRADS (0-I-2-3-4a) & $(2 \mid-55-12-12-0-0)$ & $(29-32-24-9-0-5)$ & \\
\hline Ultrasound results & $34-5-18$ & $11-3-7$ & 0.7 \\
\hline Normal-duct ectasia -intraductal lesion & $(60-8-32)$ & $(53-15-32)$ & \\
\hline Magnetic resonance imaging findings & $6-33-4-14$ & $3-12-1-5$ & 0.95 \\
\hline None-normal-duct ectasia-intraductal lesion & $(10-58-7-25)$ & $(14-57-5-24)$ & \\
\hline Cytology & $4-26-3-24$ & $1-8-2-10$ & 0.8 \\
\hline None-normal or insignificant-atypia-papilloma suspected & $(7-46-5-42)$ & $(5-38-9-48)$ & \\
\hline
\end{tabular}

Table 3. Pathology results of the patients

\begin{tabular}{|c|c|c|c|c|c|}
\hline \multirow[t]{2}{*}{ Parameters } & \multicolumn{2}{|c|}{ Group Micro $(n=57)$} & \multicolumn{2}{|c|}{ Group Major $(n=2 I)$} & \multirow[t]{2}{*}{$\mathbf{p}$} \\
\hline & $\mathbf{n}$ & $\%$ & $\mathbf{n}$ & $\%$ & \\
\hline Duct ectasia-periductal mastitis & 17 & 29.8 & 6 & 28.6 & 0.9 \\
\hline Ductal hyperplasia & 3 & 5.3 & 1 & 4.8 & 0.9 \\
\hline Papillomatous lesion(s) without atypia & 26 & 45.6 & 8 & 38.1 & 0.4 \\
\hline Papillomatous lesion(s) with atypia & 5 & 8.8 & 2 & 9.5 & 0.9 \\
\hline Ductal carcinoma in situ & 4 & 7 & 2 & 9.5 & 0.7 \\
\hline Intraductal papillary carcinoma & 2 & 3.5 & 2 & 9.5 & 0.3 \\
\hline *In-situ cancer & 6 & 10.5 & 4 & 19 & 0.3 \\
\hline
\end{tabular}

"Ductal carcinoma in situ and intraductal papillary carcinoma.

Table 4. Comparison of lesion rate and malignancy potential

\begin{tabular}{|c|c|c|c|c|c|}
\hline \multirow[t]{2}{*}{ Parameters } & \multicolumn{2}{|c|}{ Group Micro $(n=57)$} & \multicolumn{2}{|c|}{ Group Major $(n=2 I)$} & \multirow[t]{2}{*}{$\mathbf{p}$} \\
\hline & $\mathbf{n}$ & $\%$ & $\mathbf{n}$ & $\%$ & \\
\hline Malignancy-potential lesion + (\%) & 11 & 19.3 & 6 & 28.6 & 0.3 \\
\hline Malignancy-potential lesion - (\%) & 46 & 80.7 & 15 & 71.4 & \\
\hline
\end{tabular}

MPL: Malignancy-potential lesion (atypia-containing papilloma + ductal carcinoma in situ + intraductal papillary carcinoma).

methods. ${ }^{[8]}$ However, malignancies of various grades are detected in $4 \%$ to $28 \%$ of patients with PND. ${ }^{[5,6]}$ Therefore, exclusion of malignancy is essential in these patients.

Sauter et al., ${ }^{[9]}$ researched predictive factors for occult cancers in women with PND in a study comprising 175 patients. Discharge was found to have no blood in $75 \%$ of the patients diagnosed with cancer. Papilloma was the most frequently detected lesion in patients with bloody discharge, while hyperplasia was most frequently detected in patients with bloodless discharge.

Khan et al., ${ }^{[10]}$ grouped patients according to the number of positive criteria in their research of the value of 
ductoscopy and they reported that using ductoscopy a papillomatous lesion was found in $79 \%$ of the patients with 3 positive criteria and in $21 \%$ of the patients with 2 positive criteria. In this study, they performed diagnostic duct excision on patients diagnosed with papillomatous lesions and also followed up those without lesions. They detected DCIS, which cannot be detected with ductoscopy, in $16 \%$ of patients with 3 criteria and $8 \%$ of patients with 2 criteria. They did not detect any lesions after 48 months of follow-up in 21 patients. The authors reported that ductoscopy may be sufficient in patients with 2 positive criteria, but excision should be performed in patients with 3 positive criteria. Another drawback of ductoscopy is that a significant portion of occult lesions that lead to nipple discharge are located in the lobules around the terminal ducts, which cannot be reached with ductoscopy. [II] Though the ability to reach proximal ducts with thinner ductoscopes has improved recently, ${ }^{[12]}$ Dietz et al., ${ }^{[1]}$ reported that they could visualize the proximal duct of only 34 of 42 patients (8I\%) and the subsegmental duct of 22 patients $(52 \%)$ using a $1.2 \mathrm{~mm}$ ductoscope. Other disadvantages of the ductoscope include the fact that the device is extremely expensive, fragile, and requires special training to operate. Many centers, such as ours, do not have a ductoscope.

Smear cytology from a discharge sample is also used in the diagnosis of PND. However, cytology alone cannot distinguish intraductal papilloma, atypical ductal hyperplasia, or DCIS. Furthermore, sensitivity and specificity rates vary greatly in studies researching the value of cytology in determining malignancy in PND. Kalu et al., ${ }^{[13]}$ determined the sensitivity of cytology to be $74.5 \%$ and specificity to be $30 \%$ in a retrospective study, while Ohlinger et al., ${ }^{[14]}$ determined the sensitivity of cytology to be $57.8 \%$ and specificity to be $85.2 \%$ in a another retrospective study.

Ductography is also a frequently utilized examination in cases of nipple discharge. Cabioglu et al., ${ }^{[3]}$ reported that ductography was superior to mammography and ultrasonography in detecting intraductal lesions in their retrospective study in which they examined I 46 patients. Sharma et al., ${ }^{[15]}$ reported in their study of 148 patients that ductography was not able to be performed appropriately due to technical reasons in $33 \%$ of patients, and that the sensitivity and positive predictive values were low. Since ductography is not a preferred diagnostic method in our clinic, none of the patients in our study received ductography.

Nakahara et al., ${ }^{[6]}$ reported a positive predictive value of magnetic resonance imaging (MRI) in detecting malignant lesions of $100 \%$ and a negative predictive value of $87.5 \%$ in their study comprising 55 patients with bloody nipple discharge comparing ductography, ultrasonography, and gadolinium contrast medium MRI. In a more recent study, Sanders et al., ${ }^{[17]}$ reported the sensitivity and specificity of
MRI as $87.5 \%$ and $71.4 \%$, respectively. In our study, ductal ectasia or intraductal lesion was detected in only $30 \%$ of patients who underwent MRI.

Unfortunately, the value of noninvasive examinations in the diagnosis of nipple discharge is quite limited. As such, the most effective method for the diagnosis of these patients is surgical removal of the duct that is the source of the pathological flow. Two methods are used. The first is subareolar excision of all of the ducts of the breast exhibiting PND, and the other is a less invasive microductectomy procedure, which, importantly, does not disrupt the lactation ability of women of childbearing age. Both techniques are frequently applied; however, the number of studies comparing the results is extremely limited. We found only I publication that compared these methods in searches of English and Turkish literature. Sharma et al.," ${ }^{[5]}$ of the Cleveland Clinic found a close rate of atypical ductal hyperplasia in both groups ( $9 \%$ vs $10 \%$ ) in a study comprising 235 patients, but the rate of occult carcinoma detected in the MDE group was statistically significantly higher compared to the microductectomy group ( $9 \%$ vs $3 \%$ ). The rate of intraductal lesion with atypia was similar in both groups (8.8\% vs $9.5 \%$ ) in our study. Invasive cancer was not found in our study population, while in situ carcinoma was detected in $19 \%$ of patients in the MDA group and in $10.5 \%$ of patients in microductectomy group. Though the rate of in situ carcinoma detected in the MDE group was almost 2 times that found in the microductectomy group, the difference was not statistically significant. All other clinical data of both groups investigated were found to be similar in our study.

The main limitation of our study is the retrospective collection of our data. The volume and weight of the samples removed using both methods could not be compared. Another limitation is that the operations were performed by different surgeons at different times.

\section{Conclusion}

Though many patients presenting at polyclinics with nipple discharge may have benign lesions, in some cases it may be a potentially malignant or malignant lesion. Conventional imaging modalities and cytology are not sufficient for diagnosis and surgery should be recommended even if results are negative. The surgical procedure performed may be microductectomy or MDE. Microprojection will be preferred for women who are pre-menopausal and who plan to become pregnant, as it does not disturb breast feeding function. The rate of malignancy was higher in the MDE group in our study; however, the difference was not statistically significant. The number of studies in the literature comparing these 2 methods is very limited and prospective, randomized studies with high evidence value are necessary to confirm the results of our research. 
Ethics Committee Approval

Ethics Committee of Kartal Dr. Lütfi Kırdar Training and Research Hospital.

\section{Informed Consent}

The study design was retrospective observational study.

Peer-review

Internally peer-reviewed.

Authorship Contributions

Concept: K.Ç.; Design: M.E., K.Ç., M.K.; Data collection \&/or processing: K.Ç., M.E., H.E.S., E.G., M.F.K.; Analysis and/or interpretation: K.Ç, M.K.; Literature search: M.K., K.Ç., H.E.S.; Writing: M.K., K.Ç., L.K.; Critical review: M.K., N.B.

Conflict of Interest

None declared.

\section{REFERENCES}

1. Paterok EM, Rosenthal H, Säbel M. Nipple discharge and abnormal galactogram. Results of a long-term study (1964-1990). Eur J Obstet Gynecol Reprod Biol 1993;50:227-34. [CrossRef]

2. Leis HP Jr, Greene FL, Cammarata A, Hilfer SE. Nipple discharge: surgical significance. South Med J 1988;81:20-6. [CrossRef]

3. Cabioglu N, Hunt KK, Singletary SE, Stephens TW, Marcy S, Meric $\mathrm{F}$, et al. Surgical decision making and factors determining a diagnosis of breast carcinoma in women presenting with nipple discharge. J Am Coll Surg 2003;196:354-64. [CrossRef]

4. Hussain AN, Policarpio C, Vincent MT. Evaluating nipple discharge. Obstet Gynecol Surv 2006;61:278-83. [CrossRef]

5. Vargas HI, Vargas MP, Eldrageely K, Gonzalez KD, Khalkhali I. Outcomes of clinical and surgical assessment of women with pathological nipple discharge. Am Surg 2006;72:124-8.

6. Goksel HA, Yagmurdur MC, Demirhan B, Isiklar I, Karakayali H, Bilgin N, et al. Management strategies for patients with nipple dis- charge. Langenbecks Arch Surg 2005;390:52-8. [CrossRef]

7. Dooley WC, Ljung BM, Veronesi U, Cazzaniga M, Elledge RM, O'Shaughnessy JA, et al. Ductal lavage for detection of cellular atypia in women at high risk for breast cancer. J Natl Cancer Inst 2001;93:1624-32. [CrossRef]

8. Makita M, Sakamoto G, Akiyama F, Namba K, Sugano H, Kasumi F, et al. Duct endoscopy and endoscopic biopsy in the evaluation of nipple discharge. Breast Cancer Res Treat 1991;18:179-87. [CrossRef]

9. Sauter ER, Schlatter L, Lininger J, Hewett JE. The association of bloody nipple discharge with breast pathology. Surgery 2004;136:780-5. [CrossRef]

10. Khan SA, Mangat A, Rivers A, Revesz E, Susnik B, Hansen N. Office ductoscopy for surgical selection in women with pathologic nipple discharge. Ann Surg Oncol 2011;18:3785-90. [CrossRef]

11. Dietz JR, Kim JA, Malycky JL, Levy L, Crowe J. Feasibility and Technical Considerations of Mammary Ductoscopy in Human Mastectomy Specimens. Breast J 2000;6:161-5. [CrossRef]

12. Kamali S, Harman Kamali G, Akan A, Simşek S, Bender O. Use of ductoscopy as an additional diagnostic method and its applications in nipple discharge. Minerva Chir 2014;69:65-73.

13. Kalu ON, Chow C, Wheeler A, Kong C, Wapnir I. The diagnostic value of nipple discharge cytology: breast imaging complements predictive value of nipple discharge cytology.J Surg Oncol 2012;106:381-5.

14. Ohlinger R, Stomps A, Paepke S, Blohmer JU, Grunwald S, Hahndorf W, et al. Ductoscopic detection of intraductal lesions in cases of pathologic nipple discharge in comparison with standard diagnostics: the German multicenter study. Oncol Res Treat 2014;37:628-32.

15. Sharma R, Dietz J, Wright H, Crowe J, DiNunzio A, Woletz J, et al. Comparative analysis of minimally invasive microductectomy versus major duct excision in patients with pathologic nipple discharge. Surgery 2005;138:591-6. [CrossRef]

16. Nakahara H, Namba K, Watanabe R, Furusawa H, Matsu T, Akiyama $\mathrm{F}$, et al. A comparison of MR imaging, galactography and ultrasonography in patients with nipple discharge. Breast Cancer 2003;10:320-9. [CrossRef]

17. Sanders LM, Daigle M. The Rightful Role of MRI after Negative Conventional Imaging in the Management of Bloody Nipple Discharge. Breast J 2016;22:209-12. [CrossRef]

\section{Patolojik Meme Başı Akıntılı Hastaların Tanı ve Tedavisinde Majör Duktal Eksizyon ile Minimal İnvaziv Mikroduktektomi'nin Karşılaştırılması}

Amaç: Patolojik meme başı akıntısı nedeni ile tanı ve tedavi amaçlı mikroduktektomi yapılan hastalar ile majör duktus eksizyonunu (MDE) yapılan hastaları karşılaştırmayı amaçladık.

Gereç ve Yöntem: Ekim 201 I ile Ekim 2015 tarihleri arasında, kliniğimizde patolojik meme başı akıntısı sebebiyle opere edilen hastalar dahil edildi. Veriler, hasta dosyaları incelenerek geriye dönük olarak toplandı. Hastalar yapılan cerrahi işleme göre iki gruba ayrıldı (mikrodukdektomi yapılan hastalar Grup Mikro, MDE yapılan hastalar ise Grup Majör). Çalışmamızda incelenen veriler, hastaların demografik özellikleri, akıntının karakteri, ameliyat öncesi görüntüleme bulguları, ameliyat öncesi sitolojik bulgular, ameliyat sonrası patolojik bulgular ve takip sonuçları şeklinde idi.

Bulgular: Toplam 78 hastanın 57'sine mikroduktektomi, 2 l'ine ise MDE uygulandı. Çalışmamızda her iki grupta da en sık saptanan lezyonlar atipi içermeyen papillamatöz lezyon veya lezyonlardı (sırasıyla, $n=8, \% 38$.I ve $n=26, \% 45.6$ ). Çalışmamızda toplam I7 (\%2I.8) hastada malignite potansiyeli taşıyan (atipik duktal hiperplazi, atipi içeren papillamatoz lezyon/lar, DCIS, intraduktal papiller karsinom) lezyon tespit edildi. Her ne kadar Grup Majör'de malignite potansiyeli taşıyan lezyonlu hasta sayısı Grup Minör'e oranla fazla bulunmuş olsada ( $\mathrm{n}=\mathrm{II}$, \%28.6 karşın $\mathrm{n}=6, \%$ |9.3) aradaki fark istatistiksel olarak anlamlılık göstermedi $(\mathrm{p}=0.3)$.

Sonuç: Meme başı akıntılarının tanısında klasik görüntüleme yöntemleri ve sitoloji yeterli olmayıp negatif olsalar dahi hastalara cerrahi önerilmelidir. Seçilecek cerrahi prosedür mikroduktektomi veya majör duktus eksizyonu olabilir. Nitekim bizim çalışmamızda da her iki prosedürün malignite tespit etme oranları arasında istatistiksel anlamlı fark saptanmamıştır.

Anahtar Sözcükler: Majör duktus eksizyonu; meme başı akıntısı; mikroduktektomi. 